Dinamika Kesehatan Jurnal Kebidanan dan Keperawatan Vol 10 No. 1 Juli 2019 (ISSN: 2086-3454 EISSN: 2549-4058)

url: http://ojs.dinamikakesehatan.unism.ac.id DOI : https://doi.org/10.33859/dksm.v10i1

Hubungan Dehidrasi Dengan Komplikasi Kejang Pada Pasien Diare

Usia 0-5 Tahun Di RSD Idaman Banjarbaru

\title{
Hubungan Dehidrasi Dengan Komplikasi Kejang Pada Pasien Diare Usia 0-5 Tahun Di RSD Idaman Banjarbaru
}

\author{
Doni Wibowo',Hardiyanti'*, Subhan' \\ Program Studi Ilmu Keperawatan STIKes Cahaya Bangsa \\ Banjarmasin Kalimantan Selatan INdonesia \\ korespondensi Email: ners doniwibowo@yahoo.co.id
}

DOI: https://doi.org/10.33859/dksm.v10i1.387

\begin{abstract}
Abstrak
Latar Belakang :Diare merupakan salah satu masalah utama kesehatan masyarakat yang menjadi penyebab tingginya angka kematian pada balita di Indonesia. Dehidrasi merupakan komplikasi dari kejadian diare yang disebabkan karena tubuh mengalami kehilangan cairan 40-50 ml/kg berat badan. Gangguan keseimbangan cairan dan elektrolit akan menyebabkan perubahan konsentrasi ion di ruang ekstraseluler sehingga terjadi ketidakseimbangan potensial membrane ATP ASE, difusi $\mathrm{Na}^{+}, \mathrm{K}^{+}$ kedalam sel, depolarisasi neuron dan lepas muatan listrik dengan cepat melalui neurotransmitter sehingga timbul kejang.

Tujuan: Mengetahui hubungan antara dehidrasi dengan komplikasi kejang pada pasien diare usia 05 tahun di RSD Idaman Banjarbaru.

Metode: Jenis penelitian ini adalah penelitian korelasi, dengan metode spearmen rank. Jumlah sampel dalam penelitian ini sebanyak 23 dengan teknik accidental sampling.

Hasil: Terdapat hubungan antara dehidrasi dengan komplikasi kejang pada pasien diare usia 0-5 tahun di RSD Idaman Banjarbaru, dengan nilai $p$ value sebesar 0,001 lebih kecil dari 0,05 yang berarti memiliki hubungan yang kuat. Responden yang mengalami komplikasi kejang sebanyak 73,9 \%, responden yang mengalami dehidrasi sebanyak $87,0 \%$, dan terdapat hubungan antara dehidrasi dengan komplikasi kejang pada pasien diare usia 0 - 5 tahun di RSD Idaman Banjarbaru.
\end{abstract}

Kata Kunci: Dehidrasi, Kejang, Diare 


\title{
The Correlation between Dehydration and Complications of Seizures in Diarrhea Patients Age 0-5 Years in Idaman Hospital Banjarbaru
}

\begin{abstract}
Background: Diarrhea is one of the main problems of public health which is the cause of the high mortality rate in children under five in Indonesia. Dehydration is a complication of diarrhea caused by the body experiencing fluid loss of $40-50 \mathrm{ml} / \mathrm{kg}$ body weight. Disorders of fluid and electrolyte balance will cause changes in ion concentration in the extracellular space causing the membrane potential imbalance of ATP ASE, the diffusion of $\mathrm{Na}+, \mathrm{K}+$ into cells, depolarization of neurons and release of electrical charges rapidly through neurotransmitters resulting in seizures.

Aim: Knowing the relationship between dehydration and seizure complications in patients aged 0-5 years in Idaman Idar Banjarbaru Hospital.

Method: This type of research is correlation research, with the Spearman rank method. The number of samples in this study were 23 with accidental sampling technique.

Result: There is a correlation between dehydration and seizure complications in patients aged 0-5 years with diarrhea at Idaman Banjarbaru Hospital, with a p value of 0.001 smaller than 0.05 which means having a strong correlation. Respondents who experienced seizure complications were $73.9 \%$ and experienced dehydrated were $87.0 \%$, therefore, there is a correlation between dehydration and seizure complications in diarrhea patients aged 0-5 years in Idaman Hospital Banjarbaru.
\end{abstract}

Keywords: Dehydration, Seizures, Diarrhea

\section{Pendahuluan}

Diare merupakan penyakit yang berbasis lingkungan dan terjadi hampir di seluruh daerah geografis di dunia. Diare lebih dominan menyerang balita karena daya tahan tubuhnya yang masih lemah, sehingga sangat rentan terhadap penyebaran bakteri penyebab diare.

Diare yang disertai muntah berkelanjutan akan menyebabkan dehidrasi (kekurangan cairan).

Diare harus selalu diwaspadai karena sering terjadi keterlambatan dalam pertolongan dan mengakibatkan kematian (Cahyono, 2010).

Menurut data World Health Organization (WHO) pada tahun 2013 setiap tahunnya ada sekitar 1,7 miliar kasus diare dengan angka kematian 760.000 anak dibawah 5 tahun pada negara berkembang, anak-anak usia dibawah 3 tahun rata-rata mengalami 3 episode diare pertahun. Setiap episodenya, diare akan menyebabkan kehilangan nutrisi yang dibutuhkan anak untuk tumbuh, sehingga diare 
Dinamika Kesehatan Jurnal Kebidanan dan Keperawatan Vol 10 No. 1 Juli 2019 (ISSN: 2086-3454 EISSN: 2549-4058)

url: http://ojs.dinamikakesehatan.unism.ac.id DOI : https://doi.org/10.33859/dksm.v10i1

Hubungan Dehidrasi Dengan Komplikasi Kejang Pada Pasien Diare

Usia 0-5 Tahun Di RSD Idaman Banjarbaru

merupakan penyebab utama mal nutrisi pada

anak dan menjadi penyebab kematian kedua

pada anak berusia di bawah 5 tahun, berdasarkan data United Nation Children's

Fund (UNICEF) dan World Health

Organization (WHO) pada tahun 2013 secara

global terdapat dua juta anak meninggal dunia

setiap tahunnya karena diare.

Penyakit diare di Indonesia merupakan salah satu masalah kesehatan masyarakat yang utama. Angka kesakitan diare yang tinggi menimbulkan banyak kematian terutama pada balita. Secara keseluruhan di Indonesia pada tahun 2006 diperkirakan angka kesakitan diare meningkat sebesar 423 per 1000 penduduk pada semua usia dengan jumlah kasus 10.980 penderita dan jumlah kematian 277 balita. Tahun 2008, di Indonesia episode diare pada balita berkisar 40 juta per tahun dengan kematian sebanyak 200.000-400.000 balita (Soebagyo 2008).

Menurut data dari Dinas Kesehatan Provinsi Kalimantan Selatan angka kejadian diare pada balita di Provinsi Kalimantan Selatan pada tahun 2014 sebanyak 2.644 kasus, pada tahun 2015 sebanyak 1.209, dan tahun 2016 sebanyak 1.980 dari kasus angka kejadian di Provinsi Kalimantan Selatan masih tergolong tinggi, selain itu dapat menyebabkan kematian (Dinas Kesehatan Provinsi Kalimantan Selatan, 2017).

Dehidrasi yang terjadi pada balita ataupun anak akan cepat menjadi parah, karena seorang anak berat badannya lebih ringan daripada orang dewasa, sehingga cairan tubuhnya relatif sedikit, maka jika kehilangan sedikit cairan dapat mengganggu organ vitalnya, apalagi apabila anak belum mampu untuk mengkomunikasikan keluhannya. Dehidrasi akan semakin parah jika ditambah keluhan lain seperti mencret dan suhu badan panas, karena hilangnya cairan tubuh lewat penguapan. Kasus kematian balita karena dehidrasi masih banyak ditemukan dan biasanya terjadi karena ketidak mampuan orang tua mendeteksi tanda tanda bahaya ini (Cahyono, 2010).

Balita yang mengalami diare berkepanjangan akan menyebabkan dehidrasi. Dehidrasi akibat diare tergantung pada presentase cairan tubuh yang hilang. Dehidrasi 
Dinamika Kesehatan Jurnal Kebidanan dan Keperawatan Vol 10 No. 1 Juli 2019 (ISSN: 2086-3454 EISSN: 2549-4058)

url: http://ojs.dinamikakesehatan.unism.ac.id DOI : https://doi.org/10.33859/dksm.v10i1

Hubungan Dehidrasi Dengan Komplikasi Kejang Pada Pasien Diare

Usia 0-5 Tahun Di RSD Idaman Banjarbaru

diare yang terjadi dikatagorikan menjadi diare

tanpa dehidrasi, dehidrasi ringan,sedang dan

berat. Dehidrasi yang dialami balita

memerlukan penanganan yang tepat karena

mengingat bahaya yang disebabkan dehidrasi

berakibat fatal yaitu kehilangan cairan yang

dapat berujung pada kematian (Widoyono, 2011).

Kejang Demam adalah bangkitan kejang yang terjadi pada kenaikan suhu tubuh (suhu

rektal di atas $38^{\circ} \mathrm{C}$ ) yang disebabkan oleh proses ekstrakranium (Bararan \& Jaumar, 2013). Kejang merupakan kelainan neorologis yang paling sering ditemui pada anak, terutama pada golongan anak umur 6 bulan sampai 4 tahun (Wulandari \&Erawati, 2016).

Dehidrasi merupakan komplikasi dari kejadian diare yang disebabkan karena tubuh mengalami kehilangan cairan 40-50 ml/kg berat badan, dimana banyaknya kehilangan cairan menentukan derajat dehidrasi, dan menyebabkan gangguan pada termoregulasi di hipotalamus anterior sehingga terjadi demam. Gangguan keseimbangan cairan dan elektrolit akan menyebabkan perubahan konsentrasi ion di ruang ekstraseluler sehingga terjadi ketidakseimbangan potensial membrane ATP ASE, difusi $\mathrm{Na}^{+}, \mathrm{K}^{+}$kedalam sel, depolarisasi neuron dan lepas muatan listrik dengan cepat melalui neurotransmitter sehingga timbul kejang (Hidayat, 2009).

Data penyakit kejang ataupun kejang demam pada anak di kota Banjarbaru tidak diketahui dengan pasti, akan tetapi pada tahun 2017 terdapat kasus demam dengan 510 orang (Dinkes Kota Banjarbaru, 2017). Berdasarkan data yang diperoleh dari ruang rawat inap anak RSD Idaman Banjarbaru tercatat pada tahun 2017 ditemukan sebanyak 71 anak yang mengalami kejang.

Berdasarkan fenomena mengenai masih tingginya angka kesakitan diare yang dapat mengakibatkan dehidrasi jika tidak ditangani dengan baik. Penanganan diare yang paling penting adalah untuk menjaga hidrasi dan keseimbangan ion di dalam tubuh. Diare berkepanjangan yang tidak ditangani dapat memicu asidosis metabolik yang bisa mengakibatkan kematian oleh karena itu untuk mengembalikan cairan tubuh yang keluar saat 
Dinamika Kesehatan Jurnal Kebidanan dan Keperawatan Vol 10 No. 1 Juli 2019 (ISSN: 2086-3454 EISSN: 2549-4058)

url: http://ojs.dinamikakesehatan.unism.ac.id DOI : https://doi.org/10.33859/dksm.v10i1

Hubungan Dehidrasi Dengan Komplikasi Kejang Pada Pasien Diare

Usia 0-5 Tahun Di RSD Idaman Banjarbaru

diare maka diperlukan cairan yang tidak hanya

mengandung air, namun juga ion. Peneliti

memberikan solusi nyata dalam hal pemberian

edukasi tentang diare dan pelatihan

penanganan dini pada keluarga yang

mengalami diare untuk orang awam baik di

rumah sakit, maupun di komunitas sebagai

langkah lanjut dalam pengabdian masyarakat

guna mencegah terjadinya dehidrasi dengan

resiko kejang yang berlanjut pada kematian.

\section{Metode}

Jenis penelitian ini adalah penelitian korelasi dengan metode spearmen rank. Jumlah sampel dalam penelitian ini sebanyak 23 dengan teknik accidental sampling.

\section{Hasil}

Tabel 1 Distribusi Frekuensi Berdasarkan Data Komplikasi Kejang di RSD Idaman Banjarbaru.

\begin{tabular}{clcc}
\hline No & Komplikasi Kejang & F & $(\%)$ \\
\hline \hline 1. & Ada & 17 & $73,9 \%$ \\
2. & Tidak ada & 6 & $26,1 \%$ \\
\hline & Total Jumlah & 23 & 100 \\
\hline
\end{tabular}

Berdasarkan Tabel 1 di atas dapat dilihat bahwa responden terbanyak yang mengalami komplikasi kejang berjumlah 17 orang dengan presentasi $(73,9 \%)$ dan responden yang tidak mengalami komplikasi kejang berjumlah 6

orang dengan presentasi $(26,1 \%)$.

Tabel 2 Distribusi Frekuensi Berdasarkan Data Dehidrasi di RSD Idaman Banjarbaru

\begin{tabular}{clcc}
\hline No & Dehidrasi & Jumlah & Persentasi (\%) \\
\hline \hline 1. & Ada & 20 & $87,0 \%$ \\
2. & Tidak & 3 & $13,0 \%$ \\
\hline \multicolumn{2}{c}{ Total Jumlah } & 23 & 100 \\
\hline
\end{tabular}

Berdasarkan Tabel 2 di atas dapat dilihat bahwa responden terbanyak yang mengalami Dehidrasi berjumlah 20 orang dengan presentasi $(87,0 \%)$ dan responden yang tidak mengalami dehidrasi berjumlah 3 orang dengan presentasi $(13,0 \%)$.

Tabel 3 Tabulasi Silang Antara Dehidrasi Terhadap Komplikasi Kejang Pada Pasien Diare

\begin{tabular}{lccccc}
\hline \multicolumn{1}{c}{ Dehidrasi } & \multicolumn{5}{c}{ Komplikasi Kejang } \\
\cline { 2 - 6 } & & $\begin{array}{c}\text { Ada } \\
\text { Kejang }\end{array}$ & $\begin{array}{c}\text { Tidak } \\
\text { Ada } \\
\text { kejang }\end{array}$ & Total & Nilai \\
& & \multicolumn{5}{c}{} & P \\
\hline \hline Ada & Jml & 17 & 3 & 20 & 0,001 \\
\cline { 2 - 6 } & $\%$ & 85 & 15 & 100 & \\
\hline Tidak & Jml & 1 & 2 & 3 & \\
\cline { 2 - 6 } & $\%$ & 10 & 90 & 100 & \\
\cline { 2 - 6 } & & & & 23 & \\
\hline Jumlah & Jml & 18 & 5 & $100 \%$ & \\
\cline { 2 - 6 } Total & $\%$ & 74 & 26 & & \\
\hline & & & & & \\
\hline
\end{tabular}

Berdasarkan Tabel 3 di atas dapat digambarkan bahwa sebagian besar responden mengalami dehidrasi dengan komplikasi kejang berjumlah 17 orang $(85 \%)$, dan Responden yang mengalami dehidrasi tetapi 
Dinamika Kesehatan Jurnal Kebidanan dan Keperawatan Vol 10 No. 1 Juli 2019 (ISSN: 2086-3454 EISSN: 2549-4058)

url: http://ojs.dinamikakesehatan.unism.ac.id DOI : https://doi.org/10.33859/dksm.v10i1

Hubungan Dehidrasi Dengan Komplikasi Kejang Pada Pasien Diare

Usia 0-5 Tahun Di RSD Idaman Banjarbaru

tidak ada komplikasi kejang berjumlah 3 orang

(15\%) , sedangkan responden yang tidak dehidrasi ada kejang berjumlah 1 orang (10 \%), dan responden yang tidak dehidrasi dan tidak ada komplikasi kejang berjumlah 2 orang $(90 \%)$.

Berdasarkan hasil uji statistik yang dilakukan antara Hubungan Dehidrasi Terhadap Komplikasi Kejang Pada Pasien Diare Usia 0-5 tahun di RSD Idaman Banjarbaru, dengan menggunakan uji Spearman Rank diperoleh nilai p value sebesar 0,001 lebih kecil dari 0,05 dengan taraf tingkat kepercayaan 5\%. Hasil tersebut menunjukan adanya hubungan secara signifikan antara dehidrasi dengan komplikasi kejang pada pasien diare usia $0-5$ tahun.

\section{Pembahasan}

1. Komplikasi Kejang

Berdasarkan Tabel 1 distribusi frekuensi berdasarkan data komplikasi kejang di RSD Idaman Banjarbaru di dapatkan sebagian besar responden mengalami komplikasi kejang berjumlah
17 orang $(73,9 \%)$. Penilitian ini sejalan dengan penilitian (Muti'ah 2016) di Provinsi Jawa Barat pada tahun 2012 penderita kejang di Rumah Sakit berjumlah 2.220 untuk usia 0-1 tahun, sedangkan usia 1-4 tahun berjumlah 5.696 tahun. Kejang demam adalah kejang yang terjadi karena adanya suatu proses ekstrakranium tanpa adanya kecacatan neurologik dan biasanya dialami oleh anak-anak.

Prevalensi kejadian kejang demam pada anak umur dibawah lima tahun terjadi tiap tahun di Amerika, hampir sebanyak 1,5 juta dan sebagian besar lebih sering terjadi pada anak berusia 6 hingga 36 bulan (2 tahun), terutama pada usia 18 bulan. Insidensi kejadian kejang demam berbeda di berbagai negara. Angka kejadian kejang demam pertahun mencatat $-4 \%$ di daerah Eropa Barat dan Amerika, sebesar -10\% di India dan 8,8\% di Jepang. Kejang demam sederhana merupakan $80 \%$ diantara seluruh kejang demam (Gunawan, 2012).

Dilaporkan angka kejadian kejang pada tahun 2012-2013 3-4\% di Indonesia dari 
Dinamika Kesehatan Jurnal Kebidanan dan Keperawatan Vol 10 No. 1 Juli 2019 (ISSN: 2086-3454 EISSN: 2549-4058)

url: http://ojs.dinamikakesehatan.unism.ac.id DOI : https://doi.org/10.33859/dksm.v10i1

Hubungan Dehidrasi Dengan Komplikasi Kejang Pada Pasien Diare

Usia 0-5 Tahun Di RSD Idaman Banjarbaru

anak yang berusia 6 bulan -5 tahun

(Wibisono,2015). Kejang sangat

berhubungan dengan usia, hampir tidak

pernah ditemukan setelah 6 tahun

(Hull,2008). Ada beberapa faktor yang

berhubungan dengan kejadian kejang.

Diantaranya; umur, jenis kelamin, suhu saat kejang, riwayat kejang dan epilepsi dalam keluarga, dan lamanya demam.

(IDAI, 2014).

Faktor keturunan adalah salah satu faktor terbesar terjadinya kejang pada anak (Wardani, 2012). Kejang berulang terjadi pada $50 \%$ anak yang menderita kejang pada usia kurang dari 1 tahun dan dapat berkembang menjadi epilepsi (Behrman, 2010). Risiko epilepsi dapat terjadi setelah satu atau lebih kejang jenis apapun adalah $2 \%$ dan menjadi $4 \%$ bila kejang berkepanjangan (Hull, 2008). Kejang dapat berdampak serius seperti defisit neurologik, epilepsi, retradasi mental, atau perubahan perilaku (Wong, 2009).

Komplikasi kejang yang paling banyak terjadi adalah kejang berulang. Angka frekurensi untuk kejang dilaporkan sebesar 25-50\% (Fishman, 2006). Faktor risiko berulangnya kejang demam adalah riwayat kejang demam dalam keluarga, usia kurang dari 18 bulan, temperature kurang dari $40^{\circ} \mathrm{C}$ saat kejang pertama, kejang terjadi kurang dari 1 jam setelah onset demam (Seinfeld \& Pellock, 2013).

Dampak dari kejang demam ke sistem tubuh lain diantaranya pada otot, kulit, dan bronkus. Pada otot dan kulit mengalami kontraksi otot karena peningkatan pengaturan suhu tubuh di hipotalamus karena penyebaran toksik, sedangkan pada bronkus mengalami spasma menyebabkan anak beresiko terhadap injuri dan berlangsungnya jalan nafas (Pudiastuti, 2011).

Kejang (febris convulsion/stuip/step) yaitu kejang yang timbul pada waktu demam yang tidak di sebabkan oleh proses di dalam kepala (otak: seperti meningitis atau radang selaput otak, ensifilitis atau radang otak) tetapi diluar kepala misalnya karena ada nya infeksi di saluran 
Dinamika Kesehatan Jurnal Kebidanan dan Keperawatan Vol 10 No. 1 Juli 2019 (ISSN: 2086-3454 EISSN: 2549-4058)

url: http://ojs.dinamikakesehatan.unism.ac.id DOI : https://doi.org/10.33859/dksm.v10i1

Hubungan Dehidrasi Dengan Komplikasi Kejang Pada Pasien Diare

Usia 0-5 Tahun Di RSD Idaman Banjarbaru

pernapasan, telinga atau infeksi di saluran

pencernaan. Biasanya dialami anak usia 6

bulan sampai 5 tahun. Bila anak sering

kejang, utamanya dibawah 6 bulan,

kemungkinan besar mengalami epilepsy

(Airlangga Universty Press (AUP), 2015).

Jika anak mengalami kejang maka yang harus dilakukan yaitu jangan panik, segera longgarkan pakaiannya dan lepas atau buang semua yang menghambat saluran pernapasannya. Jadi kalau sedang makan tiba-tiba anak kejang, atau ada sesuatu di mulutnya saat kejang, segera keluarkan. Miringkan tubuh anak karena umumnya anak yang sedang kejang mengeluarkan cairan-cairan dari mulutnya. "Ini sebetulnya air liur yang banyak jumlahnya karena saraf yang mengatur kelenjar air liur tak terkontrol lagi. Kalau sedang kejang, kan, saraf pusatnya terganggu. Bukan cuma air liur, air mata pun bisa keluar.” Guna memiringkan tubuh adalah supaya cairan-cairan ini langsung keluar, tidak menetap di mulut yang malah berisiko menyumbat saluran napas dan memperparah keadaan.

2. Dehidrasi

Berdasarkan Tabel 2 distribusi frekuensi berdasarkan data dehidrasi di RSD Idaman Banjarbaru didapatkan sebanyak 20 orang $(87,0 \%)$.

Penilitian ini sejalan dengan penilitian oleh Christy (2014) dimana berdasarkan laporan bulanan diare puskesmas Kalijudan ditemukan adanya balita dengan usia 1-4 tahun yang menderita dehidrasi akibat diare. Dimana pada usia 3-5 tahun seorang anak berat badannya relatif ringan dibandingkan orang dewasa, sehingga cairan tubuhnya sedikit, maka jika kehilangan cairan dapat mengganggu organ vitalnya (Cahyono, 2010).

Analisa berdasarkan jenis kelamin Dehidrasi banyak yang dialami responden laki-laki sebanyak 15 orang $(62,2 \%)$ yang berjenis kelamin perempuan 8 orang $(34,8$ \%). Rata-rata kebutuhan air untuk setiap kategori. Misalnya, untuk perempuan 1,6 liter per hari dan laki-laki dua liter per hari. 
Dinamika Kesehatan Jurnal Kebidanan dan Keperawatan Vol 10 No. 1 Juli 2019 (ISSN: 2086-3454 EISSN: 2549-4058)

url: http://ojs.dinamikakesehatan.unism.ac.id DOI : https://doi.org/10.33859/dksm.v10i1

Hubungan Dehidrasi Dengan Komplikasi Kejang Pada Pasien Diare

Usia 0-5 Tahun Di RSD Idaman Banjarbaru

Sehingga laki-laki lebih memerlukan

kebutuhan pemasukan cairan yang banyak

dibandingkan dengan perempuan, serta

sebagian besar laki-laki lebih banyak

beraktifitasi dibandingkan dengan

perempuan yang aktifitasnya lebih sedikit.

(Tashandra 2018).

Dehidrasi akan semakin parah jika ditambah keluhan lain seperti mencret, kejang di iringi suhu tubuh badan yang tinggi, karena hilangnya cairan tubuh melalui proses penguapan. Kasus kematian balita karena dehidrasi masih banyak ditemukan dan biasanya terjadi karena ketidak mampuan orang tua mendeteksi tanda tanda bahaya ini (Cahyono, 2010).

Usia menjadi salah satu factor yang penting terhadap terjadinya dehidrasi dimana kebutuhan cairan bervariasi tergantung dari usia, karena usia akan berpengaruh pada luas permukaan tubuh, metabolisme, dan berat badan. Bayi dan anak-anak lebih mudah mengalami dehidrasi dibandingkan dengan usia dewasa. Resiko dehidrasi pada anak balita menjadi lebih besar karena komposisi

cairan tubuh yang besar dan ketikmampuan untuk memenuhi kebutuhan sendiri secara bebas.

Pada usia lanjut juga lebih rentan mengalami dehidrasi maupun keseimbangan cairan dan elektrolit dikarenakan penurunan atau ganggu fungsi ginjal atau jantung sehingga hal tersebut dapat meningkatkan keparahan dehidrasi (Huang dkk, 2014).

Akibat diare, anak akan dehidrasi sebab dia kehilangan sejumlah cairan dan elektrolit tubuh karena muntah dan diare. Dehidrasi yang dialami, mulai dari dehidrasi ringan hingga berat, bahkan ada yang mengakibatkan kematian. Dehidrasi pada anak ciri-cirinya antara lain yaitu dehidrasi ringan memiliki tanda yaitu haus, kencing sedikit dan mulut kering. Dehidrasi sedang memiliki tanda yaitu ubun-ubun besar cekung, mata cekung dan tegangan kulit menurun (Eiyta, Ardinasari, 2016). 
Dinamika Kesehatan Jurnal Kebidanan dan Keperawatan Vol 10 No. 1 Juli 2019 (ISSN: 2086-3454 EISSN: 2549-4058)

url: http://ojs.dinamikakesehatan.unism.ac.id DOI : https://doi.org/10.33859/dksm.v10i1

Hubungan Dehidrasi Dengan Komplikasi Kejang Pada Pasien Diare

Usia 0-5 Tahun Di RSD Idaman Banjarbaru

Berdasarkan fenomena mengenai

masih tingginya angka kesakitan diare

yang dapat mengakibatkan dehidrasi jika

tidak ditangani dengan baik. Penanganan

diare yang paling penting adalah untuk

menjaga hidrasi dan keseimbangan ion di

dalam tubuh. Diare berkepanjangan yang

tidak ditangani dapat memicu asidosis

metabolik yang bisa mengakibatkan

kematian, oleh karena itu untuk

mengembalikan cairan tubuh yang keluar

ketika diare, maka diperlukan cairan yang

tidak hanya mengandung air, namun juga

ion.

Minuman yang mengandung ion, seperti_minuman isotonik adalah minuman yang bisa diandalkan untuk mengembalikan ion dan cairan yang hilang saat diare. Minuman isotonik merupakan minuman yang punya kandungan ion serta gula yang hampir mirip dengan cairan tubuh. Sehingga, memudahkan tubuh untuk menyerap cairan, ion, serta gula yang ada di minuman tersebut.
Usahakan untuk menghindari

minuman yang mengandung kafein dan

minuman bersoda. Jika anak mengalami

dehidrasi karena diare, jus buah dan susu

sebaiknya dihindari. Jika tidak ditangani,

dehidrasi parah bisa menyebabkan kejang.

3. Hubungan Dehidrasi dengan Komplikasi kejang pada pasien diare

Berdasarkan Tabel 3 di atas dapat digambarkan bahwa sebagian besar responden mengalami dehidrasi dengan komplikasi kejang berjumlah 17 orang (85\%), dan Responden yang mengalami dehidrasi tetapi tidak ada komplikasi kejang berjumlah 3 orang (15\%), sedangkan responden yang tidak dehidrasi dengan kejang berjumlah 1 orang (10\%), dan responden yang tidak dehidrasi dan tidak ada komplikasi kejang berjumlah 2 orang $(90 \%)$.

Berdasarkan hasil uji statistik hubungan dehidrasi dengan komplikasi kejang pada pasien diare usia 0-5 tahun di RSD Idaman Banjarbaru menggunakan uji Spearman Rank diperoleh nilai $\mathrm{p}$ value 
Dinamika Kesehatan Jurnal Kebidanan dan Keperawatan Vol 10 No. 1 Juli 2019 (ISSN: 2086-3454 EISSN: 2549-4058)

url: http://ojs.dinamikakesehatan.unism.ac.id DOI : https://doi.org/10.33859/dksm.v10i1

Hubungan Dehidrasi Dengan Komplikasi Kejang Pada Pasien Diare

Usia 0-5 Tahun Di RSD Idaman Banjarbaru

sebesar 0,001. Sehingga dapat ditarik

kesimpulan bahwa dalam penelitian ini terdapat hubungan yang signifikan antara dehidrasi dengan komplikasi kejang.

Balita yang mengalami diare berkepanjangan akan menyebabkan dehidrasi. Dehidrasi akibat diare tergantung pada presentase cairan tubuh yang hilang. Dehidrasi diare yang terjadi dikatagorikan menjadi diare tanpa dehidrasi, dehidrasi ringan, sedang dan berat. Jika anak sudah memasuki dehidrasi maka anak akan sering merasa haus dan jumlah kebutuhan minum lebih banyak dari biasanya, mulut kering, kulit kering, anak sering rewel dan kencing sedikit. Dehidrasi yang dialami balita memerlukan penanganan yang tepat karena mengingat bahaya yang disebabkan dehidrasi berakibat fatal yaitu kehilangan cairan yang dapat berujung pada kematian (Widoyono, 2011).

Hasil penelitian diatas bahwa dehidrasi menjadi faktor yang berhubungan dengan kejadian kejang pada pasien diare sejalan dengan pernyataan Hidayat (2009),

Gangguan keseimbangan cairan dan elektrolit akan menyebabkan perubahan konsentrasi ion di ruang ekstraseluler sehingga terjadi ketidakseimbangan potensial membrane ATP ASE, difusi $\mathrm{Na}^{+}$, $\mathrm{K}^{+}$kedalam sel, depolarisasi neuron dan lepas muatan listrik dengan cepat melalui neurotransmitter sehingga timbul kejang.

Pasien dengan dehidrasi mengalami kekurangan cairan dan elektrolit yang dapat mengakibatkan demam, karena cairan dan elektrolit ini merupakan komponen yang sangat berpengaruh dalam keseimbangan termoregulasi di hipotalamus anterior, sehingga jika pasien mengalami dehidrasi maka keseimbangan termoregulasi di hipotalamus anterior akan mengalami gangguan.

Apabila anak kehilangan cairan dan elektrolit (dehidrasi), maka elektrolitelektrolit yang ada pada pembuluh darah berkurang padahal dalam proses metabolisme di hipotalamus anterior membutuhkan elektrolit tersebut, sehingga 
Dinamika Kesehatan Jurnal Kebidanan dan Keperawatan Vol 10 No. 1 Juli 2019 (ISSN: 2086-3454 EISSN: 2549-4058)

url: http://ojs.dinamikakesehatan.unism.ac.id DOI : https://doi.org/10.33859/dksm.v10i1

Hubungan Dehidrasi Dengan Komplikasi Kejang Pada Pasien Diare

Usia 0-5 Tahun Di RSD Idaman Banjarbaru

kekurangan cairan dan elektrolit

mempengaruhi fungsi hipotalamus

anterior, dalam mempertahankan

keseimbangan termoregulasi dan akhirnya

menyebabkan demam.

Peningkatan suhu tubuh dapat

mengubah keseimbangan dari membran sel

neuron dan dalam waktu singkat terjadi

difusi ion kalium dan natrium melalui

membran tersebut dengan akibat terjadinya

lepas muatan listrik. Lepas muatan listrik

ini demikian besarnya sehingga dapat

meluas keseluruh sel maupun membran sel

sekitarnya dengan bantuan bahan yang

disebut neurotransmiter dan terjadi kejang.

Kejang yang terjadi singkat pada

umumnya tidak berbahaya dan tidak meninggalkan gejala sisa. Kejang yang berlangsung lama (lebih dari 15 menit) biasanya disertai apnea, meningkatnya kebutuhan oksigen dan energi untuk kontraksi otot skelet yang akhirnya terjadi hipoksemia, hiperkapnia, asidosis laktat yang disebabkan oleh metabolisme anaerobik, hipotensi arterial disertai denyut jantung yang tidak teratur dan suhu

tubuh makin meningkat yang disebabkan

oleh makin meningkatnya aktivitas otot,

dan selanjutnya menyebabkan

metabolisme otak meningkat.

Faktor yang terpenting adalah gangguan peredaran darah yang mengakibatkan hipoksia sehingga meningkatkan permeabilitas kapiler dan timbul edema otak yang mngakibatkan kerusakan sel neuron otak. Kerusakan pada daerah medial lobus temporalis setelah mendapat serangan kejang yang berlangsung lama dapat menjadi matang dikemudian hari sehingga terjadi serangan epilepsi spontan, karena itu kejang demam yang berlangsung lama dapat menyebabkan kelainan anatomis diotak hingga terjadi epilepsi.

Begitu pentingnya pengetahuan orang tua maupun keluarga tentang diare, tandatanda dehidrasi, dan penangnan kejang dirumah. Besarnya dampak yang diakibatkan oleh diare, dehidrasi, begitu juga kejang sudah menjadi keharusan bagi 
Dinamika Kesehatan Jurnal Kebidanan dan Keperawatan Vol 10 No. 1 Juli 2019 (ISSN: 2086-3454 EISSN: 2549-4058)

url: http://ojs.dinamikakesehatan.unism.ac.id DOI : https://doi.org/10.33859/dksm.v10i1

Hubungan Dehidrasi Dengan Komplikasi Kejang Pada Pasien Diare

Usia 0-5 Tahun Di RSD Idaman Banjarbaru

tenaga kesehatan, kader kesehatan

memberikan edukasi secara kontinyu pada

kegiatan pada orang tua dalam kegiatan

posyandu, tindakan preventif tentu

menjadi solusi yang tepat untuk menekan

angka kejadian dan komplikasi dari diare

pada balita. Perlu adanya peran aktif dari

tenaga kesehatan maupun kader kesehatan

dalam memonitoring kedisiplinan

masyarakat yang memiliki anak dibawah 5

tahun dalam kegiatan posyandu.

Berkunjung dari rumah kerumah

masyarakat untuk memberikan motivasi

dan inovasi dalam sistem pelayanan

kesehatan bagi balita khususnya bagi

masyarakat yang kurang aktif/memiliki

keterbatasan dalam kegiatan posyandu.

Pelayanan yang inovatif dan berkualitas

hanya memiliki satu tujuan yaitu

peningkatan derajat kesehatan bagi

masyarakat khususnya balita.

\section{Ucapan Terimakasih}

Peneliti mengucapkan banyak terimakasih kepada RSD Idaman Banjarbaru, teman sejawat, yang telah membantu dalam proses penelitian.

\section{Daftar Pustaka}

AUP. (2015). Pusat Penerbitan dan Percetakan Universitas Airlangga. http://catalog.aup.unair.ac.id/12-

Kedokteran. Diakses pada tanggal 30 April 2019.

Behrman. (2010). Pengaruh Pendidikan Kesehatan tentang Penanganan Kejang Demam menggunakan Audio Visual Terhadap Tingkat Pengetahuan dan Sikap Ibu dengan Anak Riwayat Kejang Demam. (Skripsi). Stikes Kusuma Husada. Program Studi S1 Keperawatan.Surakarta. http://stikeskusumahusada.ac.id/skripsi. pdf. Diakses pada tanggal 30 April 2019.

Cahyono, S.B. (2010). Vaksinasi Cara Ampuh Cegah Penyakit Infeksi. Yogyakarta: kanisisus.

Christy, M.Y. (2014). Faktor Yang Berhubungan Dengan Kejadian Dehidrasi Diare Pada Balita di Wilayah Kerja Puskesmas

Kalijudan.https://ejournal.unair.ac.id/JB E/article/download/1232/1005. Diakses pada tanggal 30 April 2019.

Dinkes Kalsel. (2017). Profil kesehatan penyakit tidak menular : Banjarmasin

Dinkes Kota Banjarbaru. (2017). Profil kesehatan penyakit tidak menular : Banjarbaru 
Dinamika Kesehatan Jurnal Kebidanan dan Keperawatan Vol 10 No. 1 Juli 2019 (ISSN: 2086-3454 EISSN: 2549-4058)

url: http://ojs.dinamikakesehatan.unism.ac.id DOI : https://doi.org/10.33859/dksm.v10i1

Hubungan Dehidrasi Dengan Komplikasi Kejang Pada Pasien Diare

Usia 0-5 Tahun Di RSD Idaman Banjarbaru

Eiyta, Ardinasari. (2016). Buku Pintar Mencegah dan Mengobati Penyakit Bayi dan Anak. Jakarta : Penerbit Bestari.

Fishman. (2006). Gambaran Pengetahuan, sikap, dan perilaku ibu kejang demam. Journal Skripsi Universitas Islam Negeri Jakarta.http://repository.uinjkt.ac.id/bits ream.pdf. Diakses pada tanggal 30 April 2019.

Gunawan. (2012). Pengaruh Pendidikan Kesehatan tentang Penanganan Kejang Demam menggunakan Audio Visual Terhadap Tingkat Pengetahuan dan Sikap Ibu dengan Anak Riwayat Kejang Demam. (Skripsi). Stikes Kusuma Husada. Program Studi S1 Keperawatan,Surakarta.http://stikeskusu mahusada.ac.id/skripsi. Diakses pada tanggal 30 April 2019.

Hull. (2008). Pengaruh Pendidikan Kesehatan tentang Penanganan Kejang Demam menggunakan Audio Visual Terhadap Tingkat Pengetahuan dan Sikap Ibu dengan Anak Riwayat Kejang Demam. (Skripsi). Stikes Kusuma Husada. Program Studi S1 Keperawatan, Surakarta. Diunduh di http://stikeskusumahusada.ac.id/skripsi. pdf. Diakses Pada tanggal 30 April 2019.

IDAI. (2014). Jadwal Imunisasi Anak Umur 018 Tahun. Jakarta: Badan Penerbit IDAI.http://idai.or.id/wpcontent/uploads /2014/04/Jadwal-Imunisasi-2014 lanscape-Final.pdf. Diakses pada tanggal 30 April 2019.

Pudiastuti, R. D. (2011). Waspadai Penyakit Anak. Jakarta: Indeks.

Seinfeld \& Pellock. (2013). Gambaran Pengetahuan,sikap,dan perilaku ibu
kejang demam. Journal Skripsi Universitas Islam Negeri Jakarta. http://repository.uinjkt.ac.id/bitsream.pd f. Diakses pada tanggal 30 April 2019.

Soebagyo. (2008). Diare Akut pada Anak, Universitas Sebelas Maret Press, Surakarta.

Wardani. (2012). Pengaruh Pendidikan Kesehatan tentang Penanganan Kejang Demam menggunakan Audio Visual Terhadap Tingkat Pengetahuan dan Sikap Ibu dengan Anak Riwayat Kejang Demam. (Skripsi). Stikes Kusuma Husada. Program Studi S1 Keperawatan, Surakarta. Diunduh di http://stikeskusumahusada.ac.id/skripsi. pdf. Diakses Pada tanggal 30 April 2019.

WHO, (2013). World Health Statisitcs 2013. www.who.int/gho/publications/. Diakses pada tanggal 30 April 2019.

Wibisono. (2015). Step Dampak Kejang Demam Terhadap Pertumbuhan dan Perkembangan.http://stepdampakkejang demam.ac..id/jurnal. Diakses pada tanggal 30 April 2019.

Widoyono. (2011). Penyakit Tropis : Epidemiologi, Penularan, Pencegahan, dan Pemberantasannya. Jakarta: Erlangga.

Wong, L., Donna. (2009). Buku Ajar Keperawatan Pediatrik Wong, Ed. 6, Vol.2. Jakarta: Buku Kedokteran EGC.

Wulandari, M., Ernawati, M. (2016). Buku Ajar Keperawatan Anak. Yogyakarta :Pustaka pelajar. 